\title{
Parenthetical Cohesive Explicitness: A Linguistic Approach for a Modified Translation of the Quranic Text
}

\author{
Mohammad Amin Hawamdeh (Corresponding Author) \\ Faculty of Languages and Linguistics, University of Malaya \\ P. O. Box 50603 Kuala Lumpur, Malaysia \\ E-mail: amiin.mohammad@hotmail.com \\ Kais Amer Kadhim \\ Faculty of Languages and Linguistics, University of Malaya \\ P. O. Box 50603 Kuala Lumpur, Malaysia \\ E-mail: kaisamir@um.edu.my
}

Received: 09-02- 2015

Published: 01-09- 2015
Accepted: 17-04- 2015

doi:10.7575/aiac.ijalel.v.4n.5p.161
Advance Access Published: May 2015

URL: http://dx.doi.org/10.7575/aiac.ijalel.v.4n.5p.161

\begin{abstract}
Motivated by the severe criticism the Hilali and Khan (HK) Translation of the Holy Quran has received for its too many parenthetical insertions, this study aimed at linguistically realizing how such added pieces of information could be for necessary cohesive explicitness or worthless redundant interpolation. Methodically, the HK translation of the first 8 verses of Chapter 18 (The Cave, Surah Al Kahf) of the Holy Quran was selected to be a subject material. A number of 15 instances of explicitation put in parentheses were encountered; they were found to be based upon 23 cohesive (grammatical/lexical) relationships and, hence, to be considered as ones of cohesive explicitness. Eventually, such an analysis could be of use for modifying the available translations of the Holy Quran.
\end{abstract}

Keywords: Parenthetical Cohesive Explicitness; Grammatical/Lexical; Holy Quran; Hilali-Khan English Translation

\section{Introduction}

It is a very difficult, if not impossible, task to attain a translation that is equivalent to the original. The task is still more difficult in case of such two completely different languages as Arabic and English. Generally speaking, to translate is to show respect to both the source-language (SL) and target-language (TL) (Hatim and Mason, 1990: 9-10; Ghazala, 2008: 27) by consciously adjusting the SL structural form to the TL requirements, creating semantic equivalence by accounting for the cultural differences and aiming at equivalence in stylistic appropriateness by explaining the wayward use of a word (Nida, 1964: 45; Newmark, 1981: 91). This seems as a matter of blending between both extremes of formal and dynamic equivalence (Kasparek, 1983: 84), by which judicious acts of explicitation are to come about.

First introduced by Vinay and Darbelnet (1958/1995), the term of explicitation generally means to introduce into the TL any implicit information derived from the SL context. Definitely, this introducing must be in harmony with the TL text and, hence, carried out in a certain cohesive manner. Such added information helps fit out elliptical expressions, avoid misleading reference, restructure grammar, amplify from implicit to explicit status, answer rhetorical questions, classify proper names and borrowed terms and, also, connect parts of the text (Nida, 1964: 227-231; Newmark, 1981: 92). Blum-Kulka (1986) also stresses that "[e]xplicitation is a universal strategy inherent in the process of language mediation" (p. 21). Hence, to translate is to explicitate, i.e. to inform the TL reader of any implicitly established points of thought in the SL text (cf. Séguinot, 1988: 108; Klaudy, 1998: 82-83; Olohan and Baker, 2000: 157). This implies that additional phrases are included, implicatures are spelled out and connectives are added (cf. Kortmann, 1991; Saldanha, 2008).

Anyhow, the acts of explicitation as stated above might lead to a TL text that is more redundant. However, they help resolve ambiguity, improve cohesiveness and add linguistic and extralinguistic information (cf. Olohan and Baker, 2000: 157). Blum-Kulka (2000: 300) argues that this redundancy can be expressed as COHESIVE EXPLICITNESS, which can be highly based upon Beaugrande and Dressler's (1972: 113) argument that any configuration of language is intended to be produced as a cohesive text. Being the grammatical and lexical relationship in a text, cohesion describes how the sentential components of a text are mutually connected and the text itself looks coherent. In fact, cohesion as a concept is first introduced by Halliday and Hasan (1976) in regard to how sentences are linked in a text:

"[A] text has texture, and this is what distinguishes it from something that is not a text [...] If a passage of English containing more than one sentence is perceived as a text, there will be certain linguistic features $[\ldots]$ contributing to its total unity and giving it texture" (p. 2). 
Being a linguistic property for making a text coherent, COHESION rests upon both the grammatical dependencies (Beaugrande and Dressler, 1972: 3) and the semantic relation(s) between the elements of a text (Halliday and Hasan, 1976: 8). In this respect, the text to be constructed as a semantic edifice is systematized by five cohesive ties: reference, substitution, ellipse, conjunction and lexical cohesion (Halliday and Hasan, 1976: 13), perhaps according to what kind of topic or content the given text is of. Hasan (1984) also proposes that cohesion contributes to coherence; in other words, the former is a property of the text and the latter is a facet of the reader's evaluation of a text. Being part of the linguistic system, cohesion is the overt representation of covert coherential relations; likewise, Taboada (2004) stresses that it is a semantic relation expressed through the stratal organization of language:

"[L]anguage is organized around three different levels of coding [...] The semantic level, or stratum, represents the meanings in the language, and it is realized through the lexicogrammatical stratum, which includes the forms of the language" (Ibid., p. 159).

Furthermore, the topic of explicitation and/or cohesion has been addressed, in translation in general and in any language-pair in particular, from different perspectives:

- Heltai (2005) argued that, by explicitation, a SL piece of non-linguistically-coded information is coded by a linguistic form in the TL, or it is simply an increased level of linguistic coding.

- On the level of cohesion in translation from English into German, Hansen-Schirra (2007) concluded that explicitation can be indicated by cohesive features.

- Baleghizadeh and Sharifi (2010) argued that the explicitation of implicit logical links in translation is due to the structural differences and the translator's endeavor to make the text acceptable to the TL reader by TL natural cohesive patterns.

- Also, Guo (2011) found that explicitation in translation from Chinese into English relates to implied subjects, cohesion and coherence and grammatical meanings.

- Stressing that pragmatic loss is inevitable in translating the Quran, Azab and Othman (2012) argued that there is no pragmatic matching in translation but a kind of maximal approximation.

- Justifying lexical departure from formal correspondence on the basis of four types of meaning, Hawamdeh (2014) found that any addition is/is to be based upon a referential, collocative, connotative or situational relationship between the added piece of information and the text/context.

\section{Problem and Purpose}

The too many parenthetical additions of information in the HK Translation have been severely criticized. This Translation is seen as a shocking distortion of the Quranic message (Mohammed, 2005; Musaji, 2006; Fadl, 2005; Murphy, 2006; Crane, 2012; Schwartz, 2014). It is also argued as it neither reflects the majestic grandeur of Arabic nor does it imitates the elegance of English (Jassem, 2014: 269). Anyhow, this criticism has never been based upon a linguistic approach; it is all about how the SL text is over-translated and the TL reader is confused. Such pieces of explicitation could be false or right acts of translating; they might be necessary/informative or irregular/misleading. In fact, to highly depart from formal correspondence of the SL text definitely eliminates the reader and makes through subjective approach (cf. Stamps, 1993; Ghazala, 2008: 26). However, any translation between two completely different languages as Arabic and English is highly expected to be a demanding challenge.

Despite being a critical issue in translation in general and in translating holy texts (e.g. the Quran) in particular, this technique of parenthetical cohesive explicitness has not been a key subject of research, if not tackled at all. Still, the bibliographical material on this important subject is limited in spite of the big association between explicitation and translation. Therefore, the present study aims at analyzing how cohesive the parenthetical pieces of explicitation in the HK Translation are and, hence, how the same can be a linguistic approach to the translation of the Quranic text.

\section{Method}

The subject HK translation of the Quran into English is titled as The Noble Quran: English Translation of the Meanings and Commentary. It is the fifteenth revised edition published in 1996, as a co-translation of the Holy Quran into the modern English language by Dr. Muhammad Taqi-ud Din Al Hilali and Dr. Muhammad Muhsin Khan, formerly Professor of Islamic Faith and Teachings and Director of University Hospital at the Islamic University in Madinah, KSA, respectively. The HK Translation is sponsored by the Saudi government; it was published by King Fahd Complex for the Printing of the Holy Quran in Madinah. It is also approved by the Islamic University and the Saudi Dar Al Ifta (Mohammed, 2005; Fadl, 2005; Schwartz, 2004). For this analysis, the first section of Surah Al Kahf (Chapter 18-the Cave) of the Quran was selected a subject sample. Generally, this chapter belongs to the Makki type of revelation, ${ }^{\mathrm{i}}$ and it can be divided into an introduction, four stories and conclusion. ${ }^{\text {ii }}$

Our sample is the introduction itself; it consists of eight (8) verses and is thematically of one integral topic. ${ }^{\text {iii }}$ Procedurally, such verses were examined in terms of the parenthetical pieces of explicitation and how they were cohesively connected to the SL/TL text/context. In point of fact, each Verse was studied in an individual manner so as to eventually take a modified translation. In light of Beaugrande and Dressler (1972), Halliday and Hasan's (1976), Blum-Bulka (1986), this procedure was based upon an approach to cohesion presented by Taboada (2004: 160-166). Pursuant to this approach, cohesion is categorized into two major types: grammatical and lexical (see Figure 1). The grammatical ties of cohesion are all resources found in the grammar of the language; they are reference, substitution, ellipsis and conjunction. ${ }^{\text {iv }}$ The lexical ties of cohesion contribute to the cohesion of a text through the selection of vocabulary; they are repetition, synonymity, collocation and other semantic relationships. 


\begin{tabular}{lc} 
Grammatical & Lexical \\
\hline R. Reference & L. Lexical cohesion \\
R1. Personal & Reiteration \\
R2. Demonstrative & $\begin{array}{c}\text { L1. Same item } \\
\text { L1a. Exact } \\
\text { R3. Comparative }\end{array}$ \\
L1b. Rephrased \\
S. Substitution & L2. Synonym \\
S1. Nominal & L3. Superordinate \\
S2. Verbal & L4. Superordinate \\
S3. Clausal & L5. General Word \\
E. Ellipsis & L6. Collocation \\
E1. Nominal & \\
E2. Verbal & \\
E3. Clausal & \\
igure 1. Summary of Cohesion Types (Taboada, 2004. 166)
\end{tabular}

\section{Data Analysis}

In the subject HK Translation of the first 8-verse section in Surah Al Kahf into English, a number of 15 instances of parenthetical cohesive explicitness were encountered. Such instances were found to help cohesively keep the SL flow of speech at different degrees and produce a natural TL text; however, they were of different cohesive types (ties or relationships). By an initial statistical account, Table 1 below shows that a number of 13 (56.5\%) grammatical and 10 $(43.5 \%)$ lexical instances of parenthetical cohesive explicitness were encountered in the analyzed subject sample (see also Figure 2).

Table 1. Account of Parenthetical Cohesive Explicitness by Frequency (and Percentage)

\begin{tabular}{lcccc}
\hline Verse No. & $\begin{array}{c}\text { Number of } \\
\text { Instances }\end{array}$ & \multicolumn{3}{c}{ Number of Cohesive Relationships } \\
\cline { 3 - 5 } & 2 & 0 & 2 & Grammatical \\
\hline 1 & 4 & 4 & 5 & 2 \\
\hline 2 & 0 & 0 & 0 & 9 \\
\hline 3 & 2 & 2 & 1 & 0 \\
\hline 4 & 1 & 1 & 0 & 3 \\
\hline 5 & 3 & 3 & 1 & 1 \\
\hline 6 & 1 & 1 & 0 & 4 \\
\hline 7 & 2 & 2 & 1 & 3 \\
\hline 8 & $\mathbf{1 5}$ & $\mathbf{1 3}$ & $\mathbf{1 0}$ & $\mathbf{2 3}$ \\
\hline Total & & $56.5 \%$ & $43.5 \%$ & $100 \%$ \\
\hline Percentage & & & &
\end{tabular}

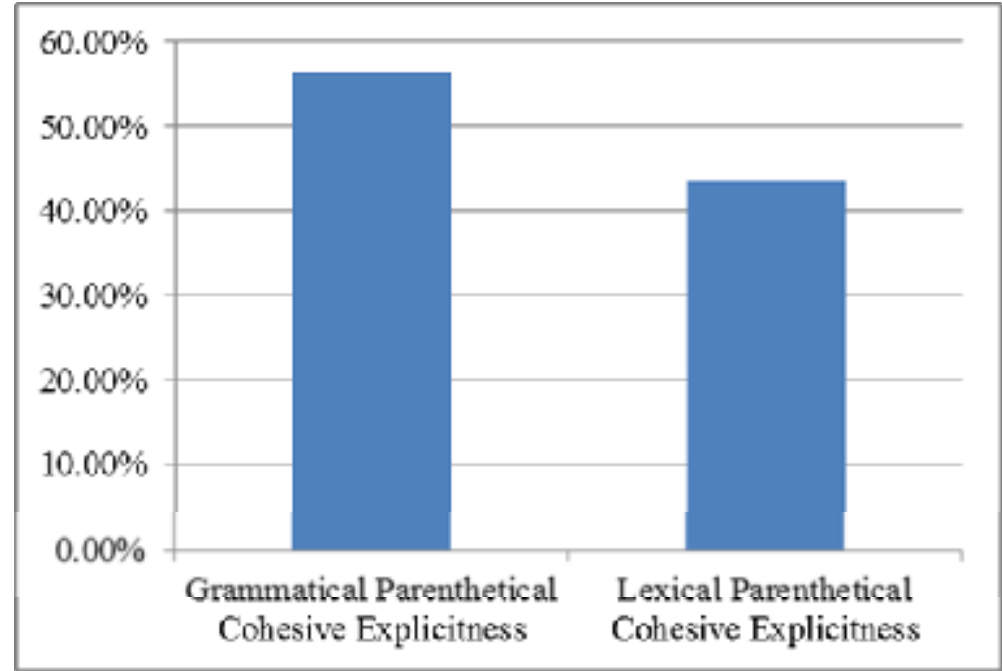

Figure 2. Illustration of the Grammatical and Lexical Instances of Parenthetical Cohesive Explicitness

In the following section, each Verse is presented along with its TL version-as just copied from the HK Translation. Also, there is an analytical description of the grammatical and lexical instances of parenthetical cohesive explicitness encountered in it, and an attempt for a more dynamically appropriate translation of the given instance in particular and, then, the Verse as a whole in general. 


\section{All the praises and thanks be to Allah, Who has sent down to His slave (Muhammad (ملى النه عله ومـلم the Book (the Qur'ân), and has not placed therein any crookedness.}

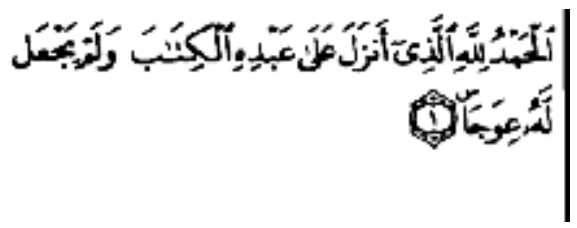

In Verse 1 as shown above, two instances of parenthetical cohesive explicitness are found:

1. The instance of [(Muhammad)] in [has sent down to His slave (Muhammad) the Book] is based upon a lexically reiterative relationship between the SL/TL unit [عبده] [His slave] and the TL [(Muhammad)] in the same Verse as the latter is a referentially nominal subordinate of and may replace the former. That is in light of a basic description that Prophet Muhammad is the intended slave upon whom Allah has sent down the Book. Therefore, it is to be read as: [has sent down to Muhammad the Book]. For a direct verb-object relation, it is to read as: [has sent down the Book to Muhammad].

2. The instance of [(the Qur'an)] in [has sent down to His slave the Book (the Qur'an)] is based upon a lexically reiterative relationship between the SL/TL unit [الكتاب] [the Book] and the TL unit [(the Qur'an)] in the same Verse as the latter is a referentially nominal subordinate of and may replace the former. That is in light of a basic description that the Holy Quran is the intended book that Allah has sent down to Prophet Muhammad. Therefore, it is to be read as: [has sent down the Qur'an to Muhammad].

Furthermore, the TL unit [and thanks] comes as an instance cohesive explicitness to be put in two parentheses. It is based upon a lexically reiterative relationship with the TL unit [praises] as it is only a synonym (or near synonym) of and may replace the latter; thus, only one of them can be used for more dynamic rendering. Eventually, the most possibly dynamic translation of Verse 1 is to be in the TL as follows: [All praises be to Allah, Who has sent down the Qur'an to Muhammad, and has not placed therein any crookedness].

2. (He has made it) straight to give
warning (to the disbelievers) of a severe
punishment from Him, and to give glad
tidings to the believers (in the Oneness of
Allah - Islâmic Monotheism), who do
righteous deeds, that they shall have a fair
reward (i.e. Paradise).

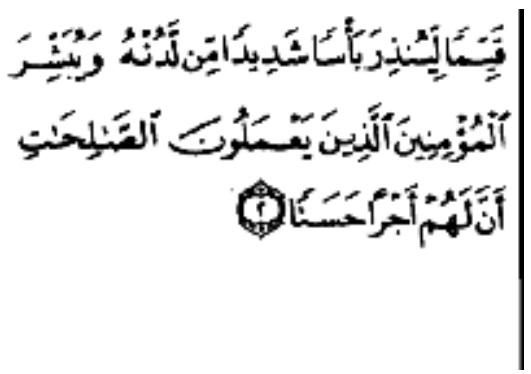

In Verse 2 as shown above, four instances of parenthetical cohesive explicitness are found:

1. The instance of [(He has made it $)]$ in [(He has made it) straight] is based upon:

a) a grammatically syntactic relationship between the SL unit [يجعل] in Verse 1 and the SL/TL unit [قيمًا] [straight] in Verse 2 as the latter is an indirect object of the former;

b) a lexically collocative relationship between the SL/TL unit [قيمًا] [straight] in Verse 2 and the SL/TL [الكتاب] [the Book] in Verse 1 as the former associates with the latter; and

c) a grammatically conjunctive relationship between the SL/TL unit [ولم يجعل له عوجًا] [and has not placed therein any crookedness] and the TL unit [Has made it] as the latter is a coordinate clause of the former (using 'and').

Therefore, it is to be read as: [and He has made it straight]. Also, for an agreement with the last SL/TL portion of Verse 1 , this requires the TL unit [placed] in Verse 1 be changed to [made] to be as [has not made therein any crookedness and He has made it straight].

2. The instance of [(to the disbelievers)] in [to give warning (to the disbelievers)] is based upon:

a) a grammatically prepositional relationship between the SL/TL unit [يعط إنذارًا] [to give warning] and the TL unit [(to the disbelievers)] in the same Verse as the latter is an adverbial phrase of the former; and

b) a lexically collocative relationship between the SL/TL unit [إنذارًا] [warning] and the TL unit [الكافرين)] [(the disbelievers)] in the same Verse as the former associates with the latter.

Therefore, it is to be read as: [to give warning to the disbelievers] or, for concise rendering and a direct verb-object relationship (see Verse 4 below), [to warn the disbelievers].

3. The instance of [(in the Oneness of Allah - Islamic Monotheism)] in [to give glad tidings to the believers (in the Oneness of Allah - Islamic Monotheism)] is based upon:

a) a grammatically prepositional relationship between the SL/TL unit [المؤمنين] [the believers] and the TL preposition [(in the Oneness of Allah - Islamic Monotheism)] in the same Verse as the latter is an adjectival phrase of the former; and

b) a lexically: 
i. collocative relationship between the SL/TL unit [المؤمنين] [the believers] and the TL unit (the Oneness of Allah) in the same Verse as the former associates with the latter, and

ii. reiterative relationship between the SL/TL unit [the believers] [المؤمنين] and the TL unit [(Islamic Monotheism)] in the same Verse as the latter is a referentially nominal subordinate of and may replace the former in light of a basic description that Islamic Monotheism is the intended belief in the oneness of Allah.

Therefore, it is to be read as: [to give glad tidings to the believers in the Oneness of Allah] or [to give glad tidings to the believers in Islamic Monotheism]. Furthermore, for more dynamic translation, it is only to be read as: [to give glad tidings to the Muslims] or, for concise rendering and a direct verb-object relationship, [to please the Muslims].

4. The instance of [(i.e. Paradise)] in [that they shall have a fair reward (i.e. Paradise)] is based upon a lexically reiterative relationship between the SL/TL [أجرًا حسنًا] [a fair reward] and the TL unit [(i.e. Paradise)] in the same Verse as the latter is a referentially nominal subordinate of and may replace the former. That is in light of a basic description that Paradise is the intended fair reward for those people who believe in the oneness of Allah. Therefore, it is to be read as: [that they shall have Paradise].

Eventually, the most possibly dynamic translation of Verse 2 is to be in the TL as follows: [...and He has made it straight to warn the disbelievers of a severe punishment from Him, and to please the Muslims, who do righteous deeds, that they shall have Paradise].

\section{They shall abide therein for ever. \\ 4. And to warn those (Jews, Christians, and pagans) who say, "Allâh has begotten a son (or offspring or children)."}

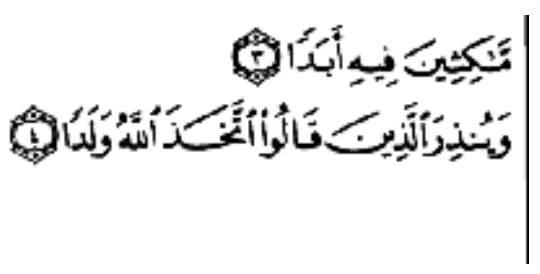

In Verse 4 as shown above, two instances of parenthetical cohesive explicitness are found:

1. The instance of [(Jews, Christians, and pagans)] in [And to warn those (Jews, Christians, and pagans) who say] is based upon a grammatically referential relationship between the SL/TL unit [الذين] [those] and the TL unit [(Jews, Christians, and pagans)] in the same Verse as the former is a modifying demonstrative of and may be replaced by the latter. This relationship is homophoric as [(Jews, Christians, and pagans)] is only in the translator's knowledge as per the Quranic exegesis. Therefore, it is to be read as: [And to warn Jews, Christians, and pagans who say].

2. The instance of [(or offspring or children)] in [who say, "Allah has begotten a son (or offspring or children)"] is based upon:

a) a grammatically conjunctive relationship between the SL/TL unit [ولدً] [a son] and the TL unit [(or offspring)] [(or children)] in the same Verse as the latter is a coordinate noun of and may replace the former; and

b) a lexically reiterative relationship between the SL/TL unit [ولدًا [a son] and the TL unit [(offspring)] [(children)] in the same Verse as the latter is a denotatively nominal synonym of and may replace the former.

Therefore, it is to be read as: in [who say, "Allah has begotten offspring"] or [who say, "Allah has begotten children"]; however, both choices are never more suitable. Thus, for preserving the singular status of the SL unit [ولًد, let us keep it as [who say, "Allah has begotten a son"].

Eventually, the most possibly dynamic translation of Verse 4 is to be in the TL as follows: [And to warn Jews, Christians, and pagans who say, "Allah has begotten a son"].

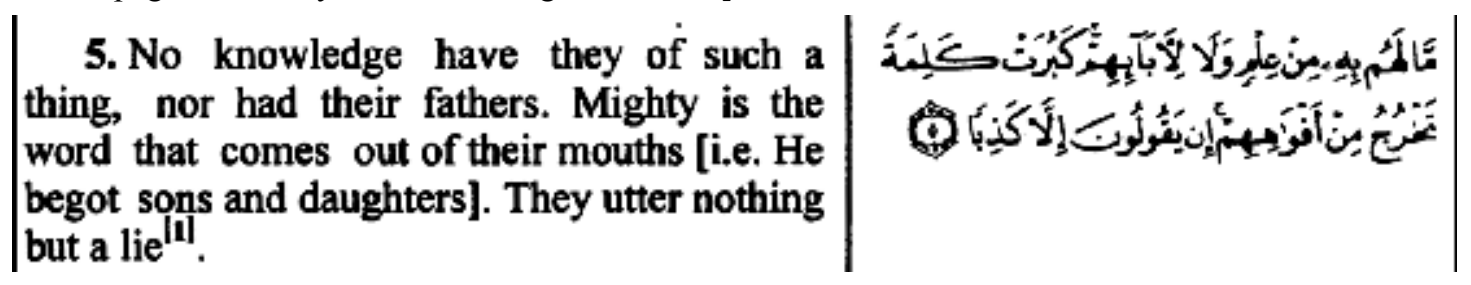

In Verse 5 as shown above, one instance of parenthetical cohesive explicitness is found.

1. The instance of [(i.e. He begot sons and daughters)] in [Mighty is the word that comes out of their mouths (i.e. He begot sons and daughters)] is based upon:

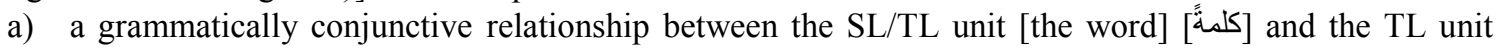
[(i.e. He begot sons and daughters)] in the same Verse as the latter is a subordinate clause of the former (using 'that'). Therefore, it is to be read as: [Mighty is the word that comes out of their mouths that He begot sons and daughters] or [...that Allah begot sons and daughters]. Also, for an agreement with Verse 4, it is to be read as [Mighty is the word that comes out of their mouths that He has begotten a son] or, for agreement with the regular TL subject-predicate structure, [The word that 
comes out of their mouths that Allah has begotten a son is mighty]. As the Quranic text in Arabic is said to originally use a parenthetical structure as one of its stylistic feature (e.g. Haleem, 1999: 94; Ahmed, 2004: 40), the Verse is to be, hence, as: [The word that comes out of their mouths (that Allah has begotten a son) is mighty].

Eventually, the most possibly dynamic translation of Verse 5 is to be in the TL as follows: [No knowledge have they of such a thing, nor had their fathers. The word that comes out of their mouths (that Allah has begotten a son) is mighty. They utter nothing but a lie].

$\mid \begin{aligned} & \text { 6. Perhaps, you, would kill yourself (O } \\ & \text { Muhammad (ملى ا ن مليه in grief, over their } \\ & \text { footsteps (for their turning away from you), } \\ & \text { because they believe not in this narration (the } \\ & \text { Qur'an). }\end{aligned}$

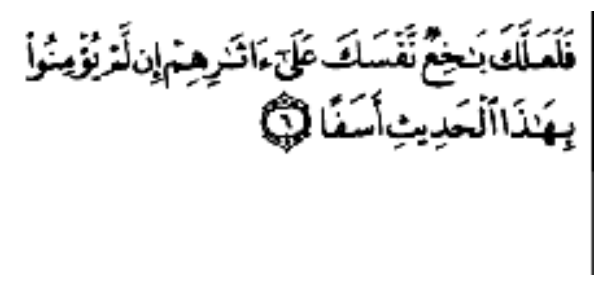

In Verse 6 as shown above, three instances of parenthetical cohesive explicitness are found:

1. The instance of [(O Muhammad $)]$ in [you would kill yourself (O Muhammad $)$ in grief] is based upon:

a) a grammatically referential relationship between the SL/TL unit [S] [you] in [فلكلع] and the TL unit $[($ Muhammad $)]$ as the former is a nominative pronoun of and may replace the latter; and

b) a grammatically conjunctive relationship between the SL/TL unit [نفسك] [yourself] and the TL unit [(O Muhammad)] as the latter is a subordinate clause of the former.

Therefore, it is to be read as: [you would kill yourself, O Muhammad, in grief].

2. The instance of [(for their turning away from you)] in [you would kill yourself, O Muhammad, in grief over their footsteps (for their turning away from you)] is based upon a grammatically prepositional relationship between the SL/TL unit [باخع نفسك] [you would kill yourself in grief] and the TL unit [(for their turning away from you)] in the same Verse as the latter is an adverbial phrase of the latter. Therefore, it is to be read as: [you would kill yourself, O Muhammad, in grief over their footsteps for their turning away from you].

3. The instance of [(the Qur'an)] in [they believe not in this narration (the Qur'an)] is based upon a lexically reiterative relationship between the SL/TL unit [هذا الحديث] [this narration] and the TL unit [(the Qur'an)] in the same Verse between as the latter is a referentially nominal subordinate of and may replace the former. That is in light of a basic description that the Qur'an is generally (and more easily to be grasped the intended narration that Prophet Muhammad would kill himself in grief for not being believed in. Therefore, it is to be read as: [they believe not in the Qur'an].

Eventually, the most possibly dynamic translation of Verse 6 is to be in the TL as follows: [Perhaps, you would kill yourself, O Muhammad, in grief, over their footsteps for their turning away from you, because they believe not in the Qur'an]. Also, for more dynamically concise rendering as no need is there for using two prepositional phrases for the TL unit [kill yourself], then, it is more appropriately to the SL-supported one, [over their footsteps], as it can have the same effect of [in grief]. Hence, the Verse is to be as: [Perhaps, you would kill yourself, O Muhammad, over their footsteps for their turning away from you, because they believe not in the Qur'an].

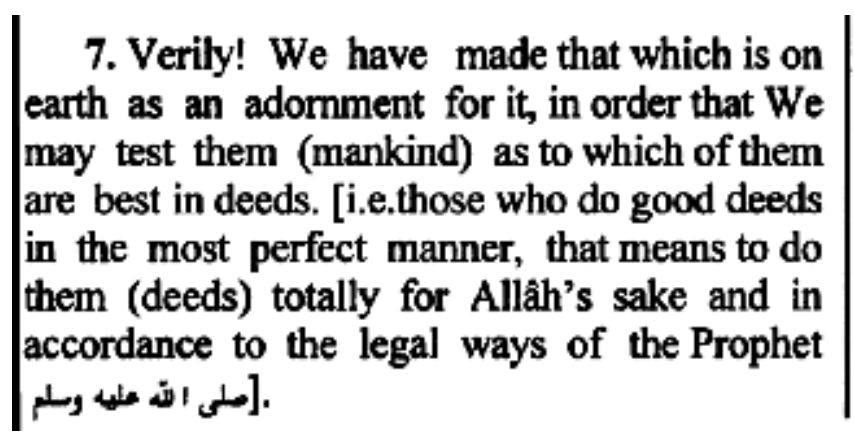

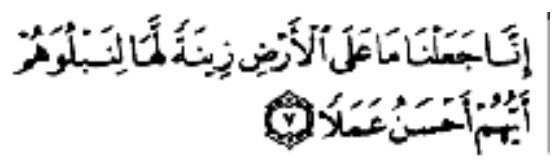

In Verse 7 as shown above, one instance of parenthetical cohesive explicitness is found: ${ }^{\mathrm{V}}$

1. The instance of [(mankind)] in [in order that We may test them (mankind)] is based upon a grammatically referential relationship between the SL/TL unit [§] [them] in [نبلوهم] and the TL unit [(mankind)] as the former is an accusative pronoun of and may be replaced by the latter. Therefore, it is to be read as follows: [in order that We may test mankind]. Eventually, the most possibly dynamic translation of Verse 7 is to be in the TL as follows: [Verily! We have made that which is on earth as an adornment for it, in order that We may test mankind as to which of them are best in deeds]. 


\section{And verily We shall make all that is on it (the earth) a bare dry soil (without any vegetation or trees.).}

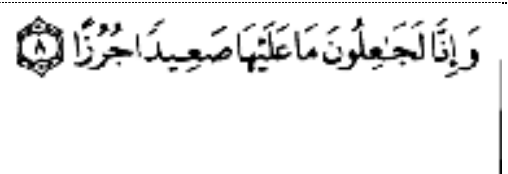

In Verse 8 as shown above, two instances of parenthetical cohesive explicitness are found:

1. The instance of [(the earth)] in [We shall make all that is on it (the earth)] is based upon a grammatically referential relationship between the SL/TL unit [\&] [it] in [عليها] and the TL unit [(the earth)] as the former is an accusative pronoun of and may be replaced by the latter. Therefore, it is to be read as: [We shall make all that is on the earth].

2. The instance of [(without any vegetation or trees)] in [a bare dry soil (without any vegetation or trees)] is based upon:

a) a grammatically prepositional relationship between the SL/TL unit ["صعيدًا جرزً] [a bare dry soil] and the TL unit [(without any vegetation or trees)] in the same Verse as the latter is an adverbial phrase of the former; and

b) a lexically reiterative relationship between the SL/TL unit [صعيدًا جرزًا] [a bare dry soil] and the TL unit [(without any vegetation or trees)] in the same Verse as the latter is a denotatively phrasal synonym (or near synonym) of and may replace the former.

Therefore, it is to be read as: [a bare dry soil without any vegetation or trees]; otherwise, it is to only use either [a bare dry soil] or [without any vegetation or trees]. However, the former choice is more fit to the SL (adjectival) usage.

Eventually, the most possibly dynamic translation of Verse 8 is to be in the TL as follows: [And verily, We shall make all that is on the earth a bare dry soil].

\section{Discussion and Conclusion}

Found to be based upon linguistic relationships, the instances of parenthetical explicitation in the first 8 verses of Surah Al Kahf in the HK Translation could be highly considered as ones of cohesive explicitness. Such instances define, illustrate and describe something in the Arabic text and help fill in the gap left in a way to continue the real sense in English. On the other hand, they interrupt the TL flow of speech and, hence, surprise the TL reader. However, some of the types of such relationships are not included in Taboada's (2004) approach to cohesion and some others are deleted. Anyhow, Figure 3 below summarizes such grammatical and lexical relationships as encountered in the subject sample in association with the aforesaid approach. ${ }^{\mathrm{vi}}$

\section{GRAMMATICAL}

\begin{tabular}{|c|c|}
\hline Reference: & $\begin{array}{l}\text { Personal/Pronominal } \\
\text { (Nominative, Accusative, } \\
\text { Possessive) } \\
\text { Demonstrative (Head, } \\
\text { Modifier) } \\
\text { Comparative (Adjectival, } \\
\text { Adverbial) }\end{array}$ \\
\hline Substitution: & $\frac{\text { Nominal }}{\underline{\text { Verbal }}}$ \\
\hline Ellipsis: & $\begin{array}{l}\text { Nominal } \\
\text { Verbal } \\
\text { Clausal }\end{array}$ \\
\hline Syntacticness: & \\
\hline Preposition: & $\begin{array}{l}\text { Adjectival (Nominal, Verbal, } \\
\text { Phrasal) } \\
\text { Adverbial (Nominal, Verbal, } \\
\text { Phrasal) }\end{array}$ \\
\hline Conjunction: & $\begin{array}{l}\text { Coordinate (Nominal, } \\
\text { Verbal, Phrasal, Clausal) } \\
\text { Subordinate (Nominal, } \\
\text { Verbal, Phrasal, Clausal) }\end{array}$ \\
\hline
\end{tabular}

LEXICAL

\begin{tabular}{ll}
\hline Repetition: & Exact Repetition \\
Rephrased Repetition \\
Reiteration: & $\begin{array}{l}\text { Denotative (Synonym, Near } \\
\text { Synonym) } \\
\text { Referential (Superordinate, } \\
\text { Subordinate, General Item) }\end{array}$
\end{tabular}

Collocation:

Figure 3. Summary of Types of Cohesive Explicitness in Reference to the HK Translation in Association with Taboada's (2004) Approach

In conclusion, a variety of procedures may be used as the SL text is analyzed and, hence, appropriate TL equivalents are thought of. In fact, to translate is to perform a highly complicated sequence of actions, including lexical replacement, grammatical restructuring, change of word-order and, also, omission and addition (cf. Nida, 1964; Nida and Taber, 1969; Newmark, 1981; Baker, 1992). In this case, the addition of information may turn out to be a necessary procedure in explicitating the SL implicit units of language in a cohesive manner. Something is always lost or gained in translation 
(Bell, 1991: 6) as long as no SL-TL sameness exists (Basnett-McGuire, 1991: 30). Definitely, languages are of different equipment for expressing the same extralinguistic contents (Ivir, 1989) or having an equal amount of the pragmatic effect on the TL audience.

\section{References}

Ahmed, Hasanuddin (2004) Introducing the Qur'ān: How to Study and Understand the Qur'ān. Goodword Books.

Azab, Amir Ebrahim Al- and Misned, Othman A. Al- (2012) Pragmatic Losses of Qur'an Translation: A Linguistic Approach. English Language and Literature Studies 2(3). DOI: 10.5539/ells.v2n3p42

Baleghizadeh, Sasan and Sharifi, Ahmad (2010) Explicitation of implicit logical links in Persian-English translation. Translation and Interpreting 2(2), 57-65.

Bassnett-McGuire, S. (1991) Translation Studies. New York and London: Routledge.

Becher, Viktor (2010) Abandoning the notion of 'translation-inherent' explicitation. Against a dogma of translation studies. Across Languages and Cultures 11(1). P.p. 1-28. DOI: 10.1556/Acr.11.2010.1.1

Beaugrande, Robert and Dressler, Wolfgang (1972) Introduction to Text Linguistics. London, New York: Longman.

Blum-Kulka, S. (1986) Shifts of Cohesion and Coherence in Translation. In Juliane House and Shoshana Blum-Kulka (Eds.) Discourse and Cognition in Translation and Second Language Acquisition Studies. Tübingen: Narr. P.p. 17-35. Reprint: Lawrence Venuti (Ed.) (2000) The Translation Studies Reader. London/New York: Routledge. P.p. 298-312.

Crane, Robert D. (2012) QUR'AN: Playing into the Hands of the Extremists? (Khan Qur'an. Islamic Research Foundation International, Inc.

Fadl, Khaled Abu El (2005) Corrupting God's Book. Chapter 57 of The Search for Beauty in Islam: A Conference of the Books. In Scholar of the House. Retrieved on July 06, 2014.

Ghazala, Hasan (2008) Stylistics and Translation: Tracing the Style of the Holy Quran and its implications in Islamic and Non-Islamic Translations. Sayyab Translation Journal (STJ) 1, 112-147.

Guo, Hong (2011) Types of Explicitation within the Texts in Chinese-English Translation: A Case Study on the Translation of Chapter Titles of Hong Lou Meng. Journal of Language Teaching and Research. Vol. 2(1). P.p. 112-119.

Haleem, Muhammad Abdel (1999) Understanding the Qur'ān Themes and Style. I. B. Tauris Publishers.

Halliday, M. A. K. and Hasan, R. (1976) Cohesion in English. London: Longman.

Hansen-Schirra, Silvia et al. (2007) Cohesive explicitness and explicitation in an English-German translation corpus. Languages in Contrast 7(2), 241-265.

Hasan, Ruqaya (1984) Coherence and Cohesive Harmony. In J. Flood (Ed.) Understanding Reading Comprehension. International Reading Association. 181-219.

Hatim, Basil and Mason, Ian (1990) Discourse and the Translator. London: Longman.

Hawamdeh, Mohammad Amin (2014) Lexical Departure from Formal Correspondence in Translation: Semantic and Pragmatic Justification. International Journal of Linguistics, Vol. 6(6),1-11. DOI: 10.5296/ijl.v6i6.6739

Heltai, Pál (2005) Explicitation, Redundancy, Ellipsis and Translation. In Károly, Krisztina, Fóris, Ágota (eds.). New Trends in Translation Studies. In Honour of Kinga Klaudy. Budapest: Akadémiai Kiadó, 45-74.

Hilali, Muhammad Taqi-ud Din Al and Khan, Muhammad Muhsin (1996) The Noble Qur'an in the English Language: A Summarized Version of At-Tabari, Al-Qurtubi, and Ibn Kathir with Comments from Sahih al-Bukhari. Madinah, KSA: King Fahd Complex.

Ivir, Vladimir (1989) Translation and Back-translation. In Yugoslav General Linguistics, Radovanović, Milorad (Ed.), $131 \mathrm{ff}$.

Jassem, Zaidan Ali (2014) The Noble Quran: A Critical Evaluation of Al-Hilali and Khan's Translation. International Journal of English and Education 3(2). P.p. 237-273.

Klaudy, Kinga (1998) Explicitation. In M. Baker (Ed), Routledge Encyclopedia of Translation Studies. London: Routledge.

Kortmann, Bernd (1991) Free Adjuncts and Absolutes in English: Problems of Control and Interpretation. London: Routledge.

Mohammed, Khaleel (2005) Assessing English Translations of the Quran.In Middle East Quarterly.

Murphy, Caryle (2006) For Conservative Muslims: Goal of Isolation a Challenge. In Washington Post. September 5.

Musaji, Sheila (2006) Through the Looking Glass: Hilali-Khan Qur'an Translation. The American Muslim Online Journal.

Newmark, Peter (1981) Approaches to Translation. Oxford and New York: Pergamon Press.

Nida, Eugene A. (1964) Towards a Science of Translating. Leiden: E. J. Brill.

Nida, Eugene A. and C. R. Taber (1969/1982) The Theory and Practice of Translation. Leiden: E. J. Brill. 
Olohan, M. and Baker, M. (2000) Reporting that in translated English. Evidence for subconscious processes of explicitation? Across Languages and Cultures 1(2), 141-158.

Pym, Anthony (2005) Defining Explicitation. In Károly, K. and Foris, Á. (Eds.). New Trends in Translation Studies. In Honour of Kinga Klaudy. Akadémiai Kiadó: Budapest.

Saldanha, Gabriela (2008) Explicitation Revisited: Bringing the Reader into the Picture. Trans-kom 1(1). P.p. 20-35.

Schwartz, Stephen (2014) Rewriting the Koran: A Bigoted Saudi Translation. In The Weekly Standard 10(3).

Séguinot, C. (1988) Pragmatics and the Explicitation Hypothesis. TTR Traduction, Terminologie, Rédaction 1(2), 106114 .

Stamps, D. (1993) Interpreting the Language of St. Paul. In Jasper, D. (Ed.) Translating Religious Texts, Translation, Transgression and Interpretation. USA: St. Martin's Press.

Taboada, Maria T. (2004). Building Coherence and Cohesion: Task-oriented Dialogue in English and Spanish. Amsterdam/Philadelphia:John Benjamins Publishing Company.

\section{Notes:}

${ }^{\mathrm{i}}$ The Makki chapters generally avoid long speeches; they focus on dogmatic themes such as monotheism, God's mercy and power, Prophethood and stories of past people and prophets.

${ }^{\text {ii }}$ The four stories in Chapter 18 of the Quran are these of the People of the Cave, the Lord of Two Gardens, Moses and Al Khidr and Dhul Qarnayn.

${ }^{i i i}$ In this topic, Allah praises Himself for sending down the Quran to His Prophet for warning the disbelievers and pleasing the believers, and assures the Prophet that the world life is going to finish.

${ }^{\text {iv }}$ Taboada (2004) omits conjunction as it is "represented in a number of conjunctive elements that are not cohesive in and of themselves" (p. 163-164).

${ }^{\mathrm{v}}$ In fact, there is a possible instance of parenthetical cohesive explicitness in Verse 7; however, it is long enough to consider it. It is more appropriately to be a kind of exegetical interpretation. Anyhow, to deal with this instance under cohesive explicitness, it is then to delete both [i.e. those who do good deeds in the most perfect manner] and [that means to do them (deeds)] as they are entirely an unnecessarily redundant additions. It is only to keep [totally for Allah's sake and in accordance to the legal ways of the Prophet] as this addition can easily be taken as an instance of cohesive

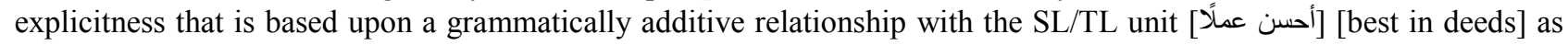
the former is prepositionally a phrasal adverb of the latter.

${ }^{\text {vi }}$ The underlined types are the ones deleted from Taboada's (2004) approach; however, the types in italics are the ones newly included. The others remain as they are. 